\title{
Hvad jeg har set i moleret! - cd om fossilerne i moleret på Mors og Fur
}

Anmeldt af geolog Ulla V. Hjuler, GeologiskNyt

Moleret er kendt for sine talrige askelag og et meget bredt spektrum af fossiler. I 2006 udgav Moler Museet på Mors en cd om disse spektakulære fossiler, som man kan finde i moleret.

Cd'en rummer en mappe med alle billed- og tekstfiler samt en registerfil, som man bruger til at finde hen til de forskellige emner.

\section{Inddeling af cd'en}

Registret rummer en oversigt over grupper af fisk, krybdyr, bunddyr, insekter, fugle og planter, som aktiveres, når man klikker på de fotos, der symboliserer grupperne. Klikker man fx på gruppen "bunddyr", ledes man videre til en oversigt over forskellige bunddyr. Vælger man eksempelvis "musling" i denne gruppe, popper der et foto samt oplysninger om fundsted, tidsperiode, længde og alder op. Supplerende oplysninger om bevarelse og placering i forhold til askelagene finder man også hér.

Har man selv fundet et spændende fossil, kan man således hurtigt finde frem til det via disse inddelinger (med mindre man selvfølgelig har fundet noget helt ukendt). Øverst i hver gruppe er der desuden en forklarende bjælke, der vha. en nummerering fra 1 til 5 fortæller om sjældenheden af det viste fund; et 1-tal ved et foto fortæller, at der kun er fundet mellem 1 og 5 eksemplarer af denne type, mens et 5-tal er et udtryk for en høj fundhyppighed på mere end 500 eksemplarer.

Der findes også et link til et kortudsnit - dog uden nogen som helst lokaliteter eller geografiske kendemærker på.

\section{Artikler}

Herefter følger tre artikler om præparation af molerfossiler, om selve moleret og om dannelsen af et fossil i moleret.

Under præparation kan man læse om, hvordan man får sit fund blotlagt uden at ødelægge det. Desuden er der nogle gode råd om syrebehandling af fossiler i cementsten samt et afsnit om brugen af gravørpind.

Artiklen om moleret fylder 26 sider og giver mange interessante oplysninger først om askelagene bl.a. nummereringen af dem

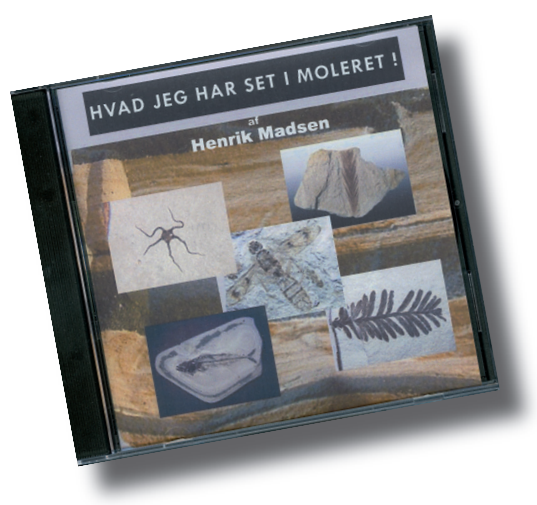

og deres bestanddele. Herefter tages der fat på moleret og dets dannelse. De næste afsnit behandler bunddyrene (bl.a. bevarelse og forekomst), istidens indflydelse på landskabet, krystaller i moleret samt molerværkernes historie og produktion. Til sidst beskrives fisk, landdyr og landområdernes planter ganske grundigt med mange gode eksempler. Alt er illustreret med fotos, kort og tegninger.

\section{Forskellige oversigter}

En liste over latinske og græske betegnelser er vist for invertebrater, vertebrater og planter (med henblik på slægter, klasser og underklasser), hvor de danske betegnelser også figurerer.

Endelig er der en tidstavle samt tre lister over fauna (bemærk! Herunder også planter), diatomeer og cementsten. De to sidstnævnte lister er bygget op ligesom oversigten over grupperne af fisk, bunddyr osv. med oplysninger om fundsted, tidsperiode $\mathrm{mv}$.

\section{Det savnede jeg}

Et par ting, der måske kunne gøre cd'en endnu bedre, ville være en oversigt over askelagsøjlen med nummereringerne på - gerne kombineret med en tidssøjle.

Kortet over lokaliteter kunne godt være udstyret med lokalitetsnavne og anden geografisk orientering, så man kan se, hvor man skal gå hen på fossiljagt - på indersiden af cd'ens cover er Thy, Fur og Mors dog vist på kortet.

Endelig er der en del sjuskefejl i de forskellige tekstelementer, som med fordel kunne rettes lidt til for at øge læsbarheden af det i øvrigt spændende indhold.

Men når det så er sagt, vil jeg bestemt anbefale cd'en, der giver en glimrende over- sigt over de mange forskellige fossiler, man kan finde i moleret, og desuden indeholder cd'en mange spændende og relevante oplysninger, der er vigtige i forbindelse med fossilbestemmelsen - eller blot interessante at vide. De mange gode fotos viser mangfoldigheden af planter, dyr og insekter, der findes i de kendte aflejringer og er samtidig en virkelig god hjælp, når man skal have bestemt sine fund!

Det er Henrik Madsen fra Moler Museet, der har stået for cd'en fra 2006. Den kan købes via museet: Skarrehagevej 8, Hesselbjerg, 7900 Nykøbing M, Telefon: 977517 16. Fax: 977517 66. Pris: 85 kr. (+ forsendelse) for en cd i plastikomslag og $100 \mathrm{kr}$. (+ forsendelse) for en cd i aeske med forside og kort. 